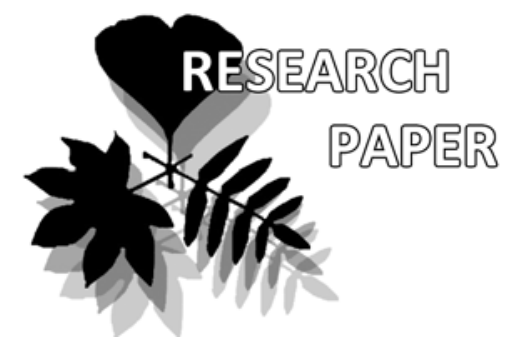

Olga V. Morozova *

e-mail: olvasmor@mail.ru

Institute of Geography RAS, Moscow, Russia

* corresponding author

Manuscript received: 27.02.2013

Review completed: 28.03.2013

Secondary review completed: 16.12.2013

Accepted for publication: 14.02.2014

\section{East Asian Species in Alien Flora of European Russia}

\author{
Olga V. Morozova
}

\section{A B S T R A C T}

Plants of East Asian origin are the important group of species introduced to many regions of the world; three of them are among 100 most widespread invasive species in Europe. Due to geographical location and vast territory of the region of European Russia, which borders with Asia and spreads across a wide range of climatic and vegetation zones, it can be considered as a transitional area between Europe and Asia. One hundred and six East Asian species comprise the second biggest group in the species pool of aliens to whole territory of European Russia and make about $5.8 \%$ of the total number of its alien plants. Invasive status of species was assessed for different regions; it may vary depending of geographical location of the species pool. Summarizing the data by regions alien flora of East Asian origin includes about $60 \%$ of casual species, $30 \%$ of naturalized and $10 \%$ are considered to be the invasive species. The majority of East Asian species (79) were brought to European Russia deliberately; the history of their introduction was similar to that in other European countries. Forty two species of them have naturalized. Twenty three species of East Asian origin were accidentally introduced, and five of them have naturalized. Some East Asian species appeared in European Russia by chance may be transported across the territory of European Russia further to Europe. Of eleven East Asian invasive species in European Russia Rosa rugosa occupied preferably the coast of the Baltic Sea, Reynoutria japonica, R. sachalinensis, Sorbaria sorbifolia and Hordeum jubatum - the Central regions of Russia, Ulmus pumila, Zizania latifolia, Cotoneaster lucidum, Hemerocallis fulva, Morus alba and Monochoria korsakowii - the southern areas of European Russia.

Ke y words

alien plants, biological invasions, East Asia, European Russia, invasive status

\section{P E 3 Ю M E}

\section{Морозова О.В. Восточноазиатские виды в чужеродной фморе Европейской России}

Восточноазиатские виды состав яют одну из значимых групп растений, заносимых во многие регионы мира; три виАа из их числа входят в список 100 наиболее распространенных инвазивных видов Европы. Благодаря географическому положению, значительной по протяженности территории и общей границе с Азией, а также широкому диапазону климатических и растительных зон и историческим связям с Азией, Европейская Россия (ЕР) преАставляет собой переходную зону межАу Европой и Азией. 106 виАОв восточноазиатского происхожАения явАяются второй по численности группой среАи виАов полностью чужеродных Аля ЕР и составАяют $5.8 \%$ от всего пула чужеродных вилов региона. Степень натурализации видов оценена Аля отдельных областей и меняется в зависимости от их географического положения. Суммируя данные по областям ЕР, среди восточноазиатских вилов отмечено около $60 \%$ случайных виАов, $30 \%$ натурамизовавшихся и 10 \% инвазивных. Большинство восточноазиатских видов (79) занесены преднамеренно, и история их интродукции на территории ЕР аналогична их появ ению в европейских странах, 42 вила из них натурализовались. 23 восточноазиатских вила - случайно занесенные, 5 из них натурализовались. Некоторые восточноазиатские виды с непреднамеренным способом заноса могут быть «транспортированы» далее в Европу. Из 11 восточноазиатских видов инвазивных на территории ЕP Reynoutria japonica, R. sachalinensis, Sorbaria sorbifolia и Hordeum jubatum расселились в основном в областях Средней России, Ulmus pumila, Zizania latifolia, Cotoneaster lucidum, Hemerocallis fulva, Morus alba и Monochoria korsakowii - в южных регионах EP, а Rosa rugosa - на побережье Балтийского моря.

ключевые слова

чужеродные растения, биологические инвазии, Восточная Азия, Европейская Россия, степень натурализации 


\section{NTRODUCTION}

Alien species are one of the major factors of global environmental change and are considered one of the most important threats to biodiversity worldwide (Simberloff 1997, Vitousek et al. 1997, Mack et al. 2000, Pyšek \& Richardson 2006). Global species exchange supposed humanmediated immigration of species from various continents by different pathways (Mack 2003, Carlton \& Ruiz 2005, Hulme et al. 2008) resulting the biotic homogenization across the globe as one of the consequences (Olden \& Poff 2003, Qian \& Ricklefs 2006, Stohlgren et al. 2011). All parts of the world except Antarctic proved to be providers of aliens, but America, Asia and Europe have served as important donor areas of alien species to various regions (Prinzing et al. 2002, Fridley 2008, Lambdon et al. 2008, Morozova et al. 2008, Phillips et al. 2010, Jiang et al. 2011).

Species of Asian origin contribute a considerable part in alien floras of many countries and continents. They prevail in alien floras of Europe (Lambdon et al. 2008) and of eastern part of United States (Friedley 2008). Usually, Asia was regarded in the whole in determining an area of species origin and as a donor region (Lambdon et al. 2008, Pyšek et al. 2012), despite the fact that its parts differ by environments and are source areas of different plant groups. East Asia as an Asian part is characterized by great diversity of climate conditions, great species number and by different centers of diversification for various plants' groups (Takhtajan 1978, Qian \& Ricklefs 2000, Qian 2002), which may be invasive beyond their native ranges. For instance, the mountains of China and the Himalayas are the origin of most cultivated and naturalizing Cotoneaster species (Dickoré \& Kasparek 2010). In addition, recent decades are marked by the growth of trade relations and the trade turnover with some East Asian countries, especially with China, which is characterized by the rapid economic development; all this may promote the appearance and the subsequent spread of new alien species from this region (Weber et al. 2008).

According to the recent review based on DAISIE project (Lambdon et al. 2008) several East Asian plant species are successful invaders in many European countries, and three of them (Reynoutria japonica, Rosa rugosa and Ailanthus altissima) are included in the list of 100 of the most invasive alien species in Europe. Presence of the species was recorded in almost all European countries; however, data from the European part of Russia (European Russia) are absent. Nevertheless, these data are required for the proper comparison of the distribution of species, assessing their ability to naturalization, and determining the ways of introduction of alien species. The latter is particularly important in connection with the fact that Russia is the largest country in the world, stretching from Europe to Asia, and its territory includes a part of Asia. Due to its geographical location and vast territory, that covers a wide range of climatic and vegetation zones Russia may represent a corridor between the West and the East, between Europe and Asia. European Russia is located in the East of Europe and has an area of 3.96 million $\mathrm{km}^{2}$ that is $24 \%$ of whole Russian territory and about $40 \%$ of the Europe's territory.
The northern part of East Asia, which refers to the territory of Russia, and European Russia have long-standing historical and cultural ties, as well as direct transport corridor. The transport system is one of the main ways of spread of alien species in the world (Mack 2003, Hulme 2009). Data from the territory of European Russia can elucidate possibilities of plants to spread and are needed both to reveal the peculiarities of establishment of several species and to estimate correct rates of the extent of their invasion.

The present study considers European Russia's alien plant species originated from one of the parts of Asia - East Asia - and aims to examine their number, growth forms, main pathways, invasive status and regional distribution.

\section{MATERIAL AND METHODS}

The information on alien species was based on the database (Morozova 2002), in which records data of European Russia's plant alien species from known published works were collected. Studies on flora in European Russia had a long history and provided a solid background for compiling a list of alien species. The first floristic research in the territory of European Russia dated back to the end of the $18^{\text {th }}$ century, and already old floral works contained information on alien plants. Special interest in alien plants dated to the first half of the $20^{\text {th }}$ century (Nazarov 1927), while after the 1960s, studies of alien species became systematic. Usually Russian botanists studied floras according administrative regions, and a good information on aliens was for many of them. The first attempt at producing the regional alien flora was carried out to the Republic of Udmurtia (Tuganaev \& Puzyrev 1988) and to the Moscow Region (Ignatov et al. 1990). Afterwards checklists of flora for some European Russia's regions began to appear. However, because of different rate of regional investigations a complete list of alien species in European Russia was absent. Our database represented the first attempt to receive more or less complete information on alien plant species of European Russia.

The database included both spatial and no spatial data (Morozova \& Borisov 2010) and consisted of several theme-based blocks: taxonomical, bibliographical and geographical. The taxonomical block contained data on alien plant species, including the taxonomy, description of species morphological, biological and ecological traits, native ranges and species settling in new territories, type of habitats, and mode of introduction into European Russia. The bibliographical block presented information about source of data, and the geographical block included data on species' records (both unpublished and published and if known with references to herbarium specimens) and invasive status of aliens in regions. A taxon was included in the database if it was found as an alien at least in one of the regions of European Russia. To standardize regional reviews and records we used the Cherepanov checklist (Cherepanov 1995) of Russia's vascular plants with additions concerning a treatment of several taxa (Maevsky 2006).

In European Russia, there are 52 administrative regions including a part of the Caucasus territory, but because of lack of data on the Ciscaucasus we analyzed species' records only from 44 ones without the Caucasus. 
To describe East Asian geographical element we defined East Asia including China, Korea, Japan and the eastern part of Russia east of Lake Baikal. We also added to analyzed set of species Sorbaria sorbifolia, which have the distribution range mainly in East Asia, and some species with native range in various continents, as for example, Hordeum jubatum that is native both to north-eastern part of Asia and to North America. We agreed to East Asian origin of Salix babylonica according to Skvortzov (1999) and the native range of Ulmus pumila according to Grudzinskaya (1977) with distribution of these species mainly in East Asia. Some taxa were excluded from the group of East Asian origin: 1) species with a large native range in Asia, distributed in more than one unit of this part of the world (e.g. Artemisia sieversiana), 2) hybrid taxa originated from East Asian species but without specifying an exact region of their direct origin as Reynoutria $x$ bohemica. Besides this, the distribution of Reynoutria $x$ bohemica in European Russia was poorly documented.

With respect to the residence time, we used the standard approach (Lambdon et al. 2008) and distinguished archaeophytes and neophytes (introduced before and after the beginning of the $16^{\text {th }}$ century).

With respect to invasion status, we determined casual, naturalized and invasive species following the approach proposed by Richardson et al. (2000). The invasive status of alien species was assessed for each of the regions whence a species was recorded.

\section{RES U LT S}

To date the dataset comprised about 1800 alien species reported from the European Russia territory. We analyzed more than 950 publications (the majority of them contained references to herbarium specimens) and it can hardly be said that this review represented the complete information. Data especially spatial distribution of aliens in regions of European Russia showed some gaps in thorough floristic inventories while such inventories with records fixation are necessary to draw conclusions on the invasion potential and on damages by alien species. However, floras of most regions were well documented, and this fact encouraged us to compile the database of alien species, which was an important instrument for comparative studies of alien floras.

In European Russia's alien flora East Asian plants numbered 106 species, this make $14.6 \%$ of species alien to the whole territory of European Russia and about $5.8 \%$ of the total number of alien species in European Russia. By regions, these species ranged from $5 \%$ to $13 \%$ of the number aliens to European Russia and from 0.4 to $7.5 \%$ of the total alien plants. There is no East Asian species recorded from all regions, and 26 species were found in more than ten regions. Almost one-third part of this species group (34 species) occurred only in one region. The most widespread species found in 20 and more regions were Hordeum jubatum, Rosa rugosa, Ulmus pumila, Fagopyrum tataricum, Panicum milliaceum, Sorbaria sorbifolia, Reynoutria japonica, Acer ginnala, Malus baccata and Thladiantha dubia; only one of them was accidental, two species have double pathway type and the others were deliberately introduced.
The East Asian alien species of European Russia showed a great diversity in their taxonomy structure and belonged to 43 families and 82 genera. Rosaceae (23 species) and Asteraceae (13 species) contributed most to this alien plant group. These two families occupied the main places in all alien flora of European Russia: Asteraceae is the second and Rosaceae - the third. Despite the fact that Asteraceae is an important source of naturalized species in the world (Pyšek 1998), only three species of this family with East Asian origin have been naturalized at least in one of the regions of European Russia, others were casuals. Fifteen species of Rosaceae were considered as naturalized and three as invasive. Rosaceae was over-represented in many alien floras and highly successful as invader in different areas (Richardson \& Pyšek 2006). Six families among the aliens to European Russia were represented only by species with East Asian origin: Actinidiaceae, Commelinaceae, Ebenaceae, Menispermaceae, Simaroubaceae and Schisandraceae.

Almost all regarded East Asian alien species were neophytes, and only one species - Panicum milliaceum - was archaeophtyte (Grigorievskaya et al. 2004, Notov 2009).

Woody and herb plants among the East Asian alien species had similar proportions in the life form distribution. However, phanerophytes (trees and shrubs) prevailed over annuals among both all East Asian alien species (47\% vs $18 \%$ ) and naturalized ones (32 species vs 3 species, Table 1). Perennial herbs amounted to $35 \%$.

With respect to the mode of introduction, 79 East Asian aliens were introduced deliberately with predominance of ornamental and horticultural purposes and only 23 species accidentally, 4 species have a double pathway of introduction.

Invasive status of alien species changed according to geographical location of regions, and the East Asian species were recorded in almost all regions (42) of European Russia except for the northernmost ones. Many of these species were casuals in some regions, and in other ones were naturalized or invasive. About $46 \%$ of the East Asian species were recorded only as casuals in all regions where species were fixed. Fifty species were classified as naturalized, and 11 species were invasive at least in one of the regions of European Russia (Tables 1, 2).

Naturalized species were presented in more than a half of the European Russia regions. The most widespread species of them (according number of regions where species were naturalized) are Sorbaria sorbifolia, Spiraea salicifolia, $S$. media, Reynoutria sachalinensis, $R$. japonica and Ulmus pumila (Appendix 1). Majority of the naturalized East Asian species was introduced deliberately. Among accidentals species only five species may be named as naturalized at least in one of the regions: Aconogonon divaricatum, Artemisia argyi, A. umbrosa, Echinochloa caudata and Potentilla tergemina.

\section{DISCUSSIO N}

The considerable extent of European Russia leads to three important points. First, as a result of the large size of the territory, the alien species set of European Russia is heterogeneous. Only $37 \%$ of alien plants found in various parts of European Russia were aliens to this territory in the whole 
Table 1. Distribution of East Asian species of European Russian alien flora in terms of invasive status

\begin{tabular}{|l|c|c|c|c|c|}
\hline Characteristics & $\begin{array}{c}\text { All Eas } \\
\text { (number of species) }\end{array}$ & Cas & Nat & Inv & Not clear \\
\hline Number of families & 43 & 42 & 22 & 7 & 10 \\
\hline Introduction mode & & & & & \\
deliberate & 79 & $69 / 33$ & $42 / 33$ & $6 / 12$ & $11 / 19$ \\
accidental & 22 & $23 / 33$ & $2 / 10$ & $1 / 1$ & $2 / 1$ \\
deliberate-accidental & 4 & $4 / 30$ & & & $1 / 9$ \\
\hline Life forms & 24 & $20 / 25$ & $17 / 28$ & $2 / 8$ & $5 / 8$ \\
tree & 26 & $24 / 26$ & $15 / 29$ & $3 / 11$ & $3 / 7$ \\
shrub & 37 & $33 / 28$ & $15 / 28$ & $5 / 15$ & $5 / 9$ \\
perennial & 18 & $19 / 35$ & $3 / 3$ & $1 / 1$ & $1 / 1$ \\
annual & $106 / 42$ & $96 / 38$ & $50 / 33$ & $11 / 23$ & $14 / 21$ \\
\hline Total & & & \\
\hline
\end{tabular}

Invasive status: cas - casual, nat - naturalized (not including invasive), inv - invasive, not clear - unknown invasive status. Numerator of the fraction is the number of species, denominator of the fraction is the number of regions where species with named status were recorded

Table 2. East Asian alien plant species invasive in European Russia (at least in one of the regions)

\begin{tabular}{|l|c|c|c|c|}
\hline Species & $\mathbf{1}^{\text {st }}$ record & Life form & Reg_all & Reg_inv \\
\hline Cotoneaster lucidus & 1935 & Shrub & 14 & 2 \\
\hline Hemerocallis fulva & & Perennial & 12 & 1 \\
\hline Hordeum jubatum & 1914 & Perennial & 32 & 9 \\
\hline Monochoria korsakowii & 1959 & Annual & 2 & 1 \\
\hline Morus alba & & Tree & 9 & 2 \\
\hline Reynoutria japonica & 1932 & Perennial & 24 & 7 \\
\hline Reynoutria sachalinensis & 1924 & Perennial & 19 & 2 \\
\hline Rosa rugosa & & Shrub & 28 & 4 \\
\hline Sorbaria sorbifolia & 1857 & Shrub & 25 & 8 \\
\hline Ulmus pumila & $1965 ?$ & Tree & 27 & 7 \\
\hline Zizania latifolia & 1955 & Perennial & 16 & 6 \\
\hline
\end{tabular}

Reg_all - number of regions whence species was recorded, Reg_inv - number of regions where species was naturalized

(aliens to European Russia), i.e. these species had their native ranges entirely outside the boundaries of European Russia. East Asian species have the second place in this group (14.6\%) after American plants (37\%). Secondly, the variety of natural conditions provides opportunities for establishment here of species from different natural zones. Third, the establishment and, accordingly, the naturalization of alien species differ depending on the regional climate conditions. The reasons for naturalization of aliens can be explained by different factors among which environment plays one of the major roles. Although some sources (Pyšek \& Richardson 2006, Lambdon et al. 2008) pointed out to the importance of environments in the process of plant naturalization, there are surprisingly little researches demonstrating the relationship between naturalized species and climate (Thuiller et al. 2006). Alien flora of European Russia's regions exhibited spatial trends due to various climate conditions (Morozova et al. 2008) and distribution of naturalized species showed preference to some parts of territory, thus along latitudinal gradient the same species may by casual in some areas and in other naturalized or invasive. East Asian species, which are invasive in European Russia, demonstrated preferable distribution too.

Rosa rugosa occurred in many regions, but was invasive especially in the shore of the Baltic Sea and in the North-
West of Russia (in the Leningrad, Kaliningrad, Tver and Yaroslavl Regions) (Fig. 1). It was introduced in Europe as an ornamental plant at the end of $18^{\text {th }}(1796)$ and during the $19^{\text {th }}$ century, it became very popular. In Russia, it was cultivated in Botanical Gardens since the beginning of the $19^{\text {th }}$ century and as naturalized it was fixed in the second half of the $20^{\text {th }}$ century. In one of regions (Tver), where status of this species was invasive now, the first finding dated from 1971 (Notov 2009). In the native range Rosa rugosa grows on sandy or gravely beaches as well as in dune grassland communities. In its secondary (introduced) range, the species was found in similar habitats. First, as invasive $R o-$ sa rugosa occurred in a variety of seashore habitats where it might form dense thickets: on sandy, gravely or stony shores. It also occupied various human-made habitats: open habitats like road verges, railway slopes, and ruderal habitats such as building sites and field edges.

Four species (Reynoutria japonica, R. sachalinensis, Sorbaria sorbifolia, Hordeum jubatum) are invasive mainly in the Central Russia's Regions. R. japonica and R. sachalinensis were frequently cultivated as an ornamental plants in parks and gardens in many European countries; in Germany, Japanese Knotweed was also used as a forage plant and for erosion control. The history of introduction of these species was related to the $19^{\text {th }}: R$. japonica was introduced 


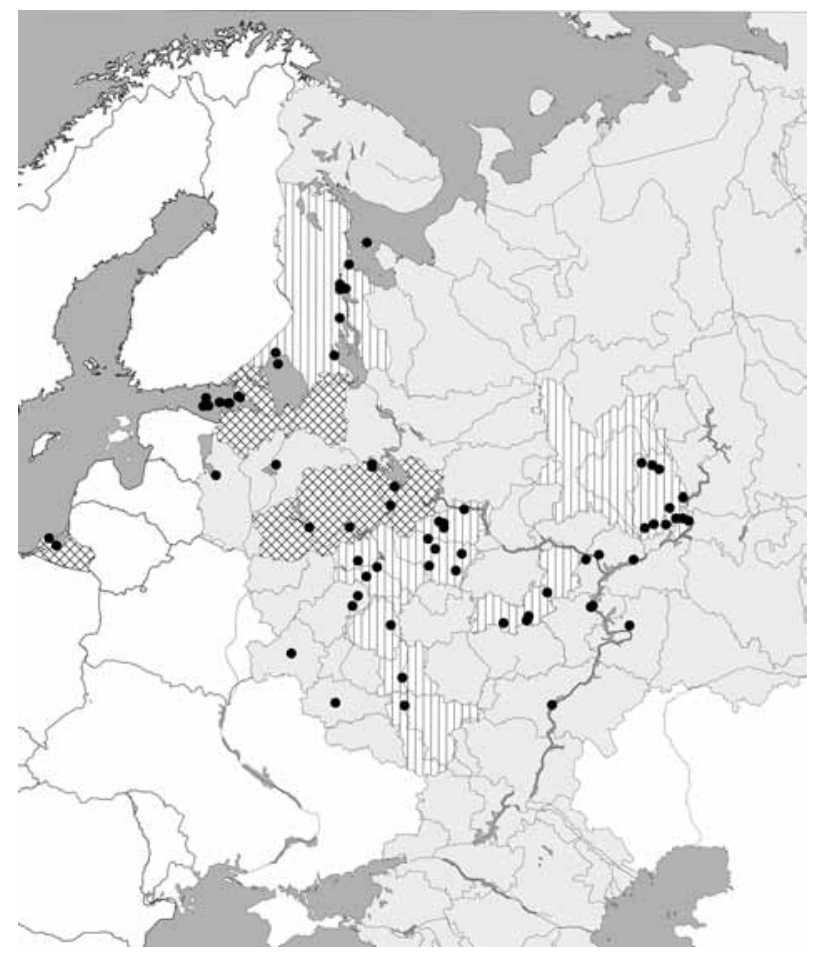

Figure 1 Findings (black circles) and invasive status of Rosa rugosa in different regions of European Russia. Invasive status of species: vertically lined area - naturalized, crossed hatching area - invasive

in Britain from China and R. sachalinensis was arrived in Europe perhaps from collection of St. Petersburg Botanical Garden; the first records were known at the middle of the century, and as naturalized, the species were fixed at the end of the one (Mandák et al. 2004). In Russia, distribution of Reynoutria species was poorly documented, a first finding of $R$. japonica in the Central Russian regions had been fixed in the first half of the $20^{\text {th }}$ century (Table 2) in the Smolensk Region (Vinogradova et al. 2009). Now R. japonica was invasive in 7 regions (Fig. 2) and $R$. sachalinensis in 2 ones. Both species were planted as ornamentals in many cities and villages whence they spread into open disturbed habitats by people, water streams or transported with soil moved during building activities.

Sorbaria sorbifolia was a very popular ornamental plant. It was introduced in Europe at the middle of the $18^{\text {th }}$ century and by now was extended as naturalized in several countries. In European Russia Sorbaria sorbifolia had the same history and time of introduction; ones of the first findings dated from 1857 in the Kursk Region (Vinogradova et al. 2009) and from 1868 in the Tver Region, where the species was found at a riverside of a small river (Notov 2009). In European Russia, the species was fixed as invasive in eight regions mainly in the Central Russia (in the Bryansk, Kaluga, Moscow, Ryazan, Tambov, Tver, Voronezh and Yaroslavl Regions). It made dense tickets, but locally and its secondary range was not continuous because little possibility of seed reproduction (Vinogradova et al. 2011).

Hordeum jubatum was introduced by two pathways: escape from cultivation as ornamental plant (at least the first records) and stowaway via transport vectors. The earliest record in European Russia was in 1914, extensive dispersal

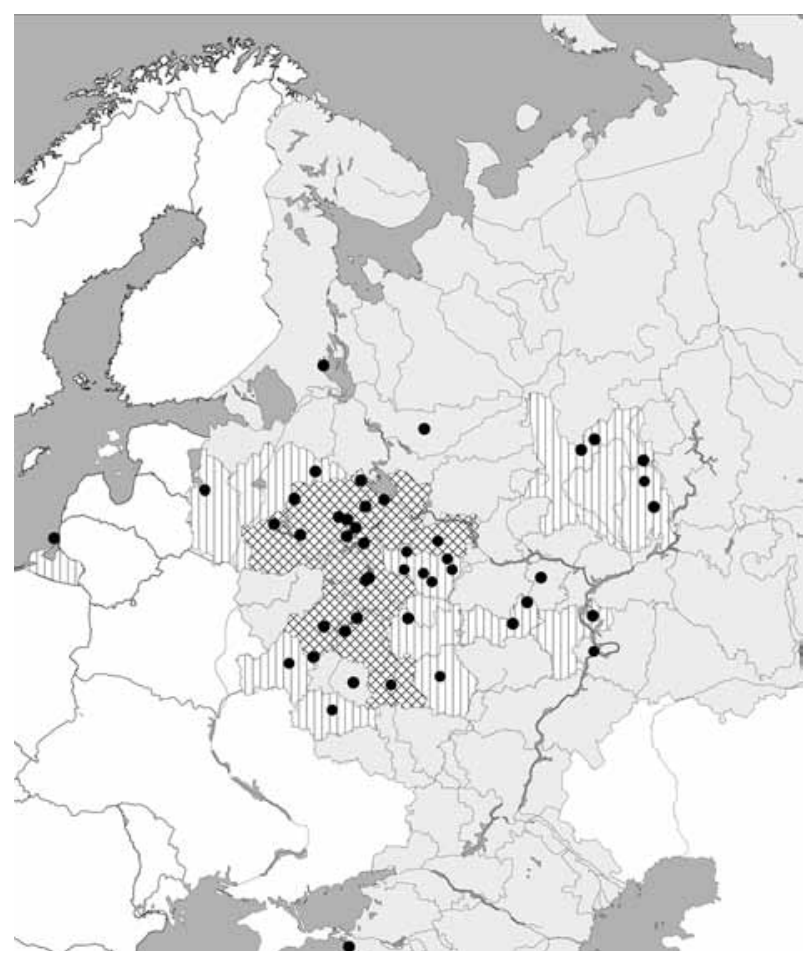

Figure 2 Findings (black circles) and invasive status of Reynoutria japonica in different regions of European Russia. For legend see Fig. 1

was fixed after sixties of $20^{\text {th }}$ century and by now Hordeum jubatum was invasive in nine regions (the Ivanovo, Lipetzk, Moscow, Ryazan, Voronezh and Saratov Regions, the Republics of Udmurtia, Mordovia, and Bashkortostan).

Six East Asian species are more common and "successful" in the southern part of European Russia. Ulmus pumila was used in many regions especially father to the south from Moscow for woodland belts, planting of tree in settlements. The pattern of naturalization (Fig. 3) showed its preference to warm climate conditions. In the introduced range, Ulmus pumila grew along railways, in forest edges and sometimes in sparse forests, in its native range the species occupied riparian gravels and sands, stony banks.

Zizania latifolia was introduced in the fifties of the last century in many water reservoirs in various regions of European Russia as a fodder plant in hunter farms. By now, it was naturalized in nine regions and in six ones was invasive. In northern regions, the species did not bear fruits and reproduced by rhizomes, in the south the bearing of Zizania was not studied but the species spread successfully along small rivers (Grigorievskaya et al. 2004). In its native range Zizania latifolia grew in shallow water of lake margins and swamps.

Cotoneaster lucidus was introduced in $19^{\text {th }}$ century as ornamental plant and by now was widely planted in towns, parks, graveyards and along roadsides. In European Russia it was observed in forest edges in two southern regions (Kursk and Voronezh).

Hemerocallis fulva is very widely grown as an ornamental plant in many countries especially with temperate climate. It was naturalized in six European Russia's regions and invasive in the Voronezh Area. 


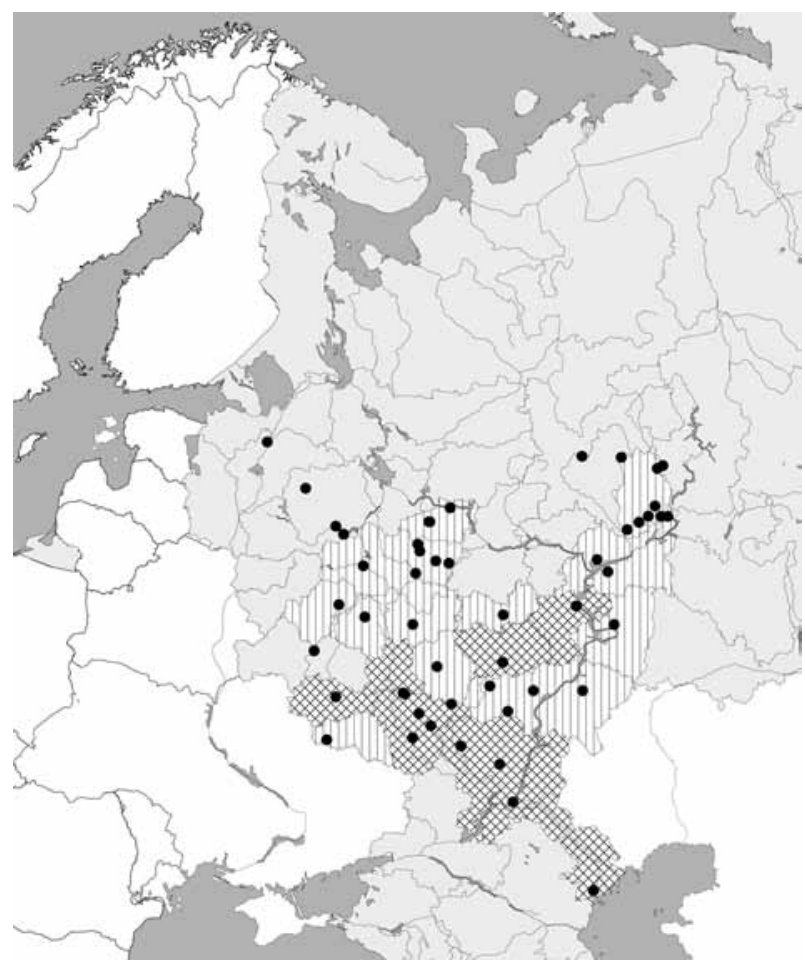

Figure 3 Findings (black circles) and invasive status of Ulmus pumila in different regions of European Russia. For legend see Fig. 1

Two species Morus alba and Monochoria korsakowii were spread only in the southernmost regions. Morus alba was cultivated in the south of European Russia as popular fruit tree and as ornamental, and now in the Krasnodar and Astrakhan Regions it was invasive. Monochoria korsakowii was introduced accidentally with seeds of rice from the Far East, and occurred only in two European Russia's regions (Astrakhan and Krasnodar). The first record was in 1959 in the Krasnodar Region. In recent years, this species was widely spread here and became a harmful weed in rice fields of the Azov-Kuban lowland that was a result of the change in technology of cultivation of rice and the use of a deep water layer for growing rice seedlings (Zelenskaya 2011).

Invasive species of East Asian origin are major or potential invaders in Europe. Three of them (Rosa rugosa, Reynoutria japonica and $R$. sachalinensis) are invasive in many European countries (Lambdon et al. 2008). Sorbaria sorbifolia suggested to be invasive in Latvia (Laiviňš et al. 2009), Lithuania, Finland and Sweden (NOBANIS www. nobanis.org). Zizania latifolia was found in Belgium (Manual of the Alien Plants of Belgium http://alienplantsbelgium.be/) and Estonia (www.nobanis.org) and was fixed in Lithuania where it had potential for further spread (Liatukas \& Stukonis 2009). Ulmus pumila was established in Austria, Italy, Romania and was potentially invasive in Latvia (www.nobanis.org). Cotoneaster lucidus was invasive in Estonia (Ööpik et al. 2008), Latvia (Laivinšs et al. 2009) and potentially invasive in Sweden and Finland (www.nobanis.org).

Fraction of East Asian species on the territory of European Russia is characterized by a high percentage of naturalized species ( $47 \%$ ). Of 50 naturalized (at least in one of the

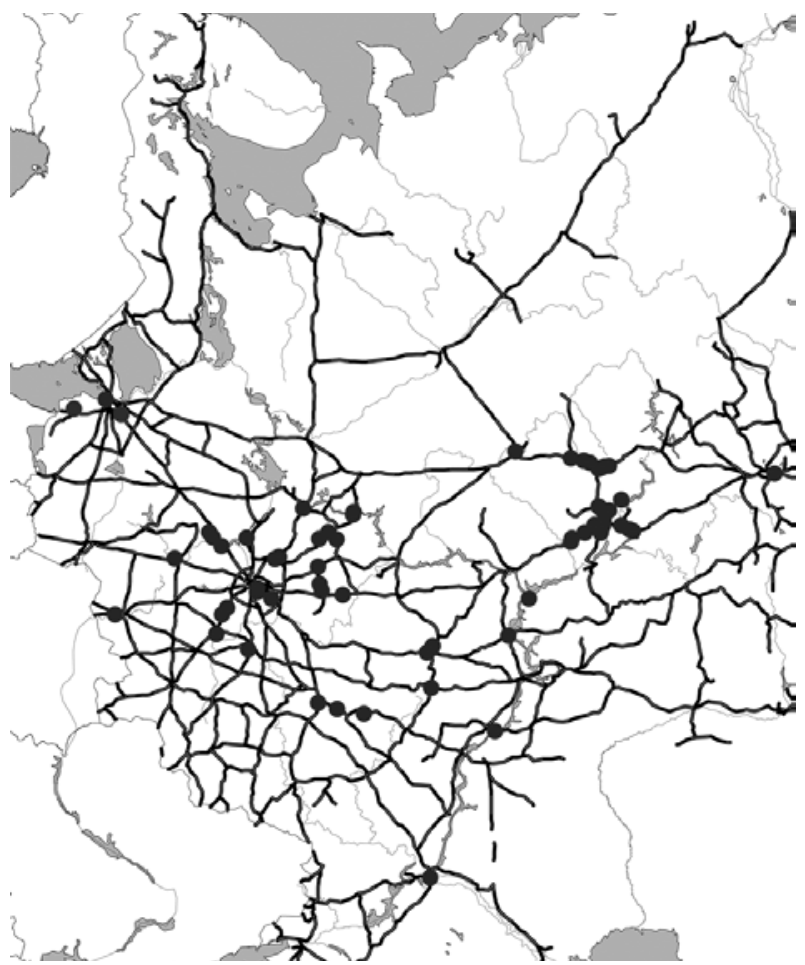

Figure 4 Findings (black circles) of Artemisia umbrosa in European Russia along main railways (bold black lines)

regions of European Russia) East Asian species, the majority were phanerophytes (32 species) and their high proportion is due to several reasons. First, these species were cultivation escapes or deliberate releases and many of them had long history of introduction for ornamental purposes as well as for forestry and for wind or soil protection. In $18^{\text {th }}$ and $19^{\text {th }}$ centuries, numerous noble estates with private parks and gardens were widely represented in European Russia where many exotic species were planted, plantings in many such sites (or parks) have been preserved up to the present time. Ornamental introduction named to be the main pathway for alien species and ornamental plants are among the most important invaders in many parts of the world (Lambdon et al. 2008, Ööpik et al. 2008, Weber et al. 2008). For woody plants, Krrivánek et al. (2005) in their study used number of sites in which a species was planted as a surrogate for propagule pressure that is a crucial factor of naturalization process (Lonsdale 1999, Pyšek \& Richardson 2006). Thus, long history of cultivation and numerous sources for escaping are responsible for the appearance and establishment of aliens. Second, absolutely predominance of woody and perennial species confirms the assumption that long-lived species have advantages for crossing both the environmental and biotic barriers and for becoming naturalized (Pyšek \& Richardson 2007). Third, majority of alien East Asian species originate from temperate regions of East Asia and it is likely that some climatic conditions in new territories are similar to those in their native areas and could facilitate a process of naturalization too.

Of East Asian accidentals, 7 species (Artemisia desertorum, Corispermum elongatum, Descurainia sophioides, Polygonum sabulosum, Securinega suffruticosa, Sphallerocarpus 
gracilis, Taraxacum sinicum) were recorded only in territory of European Russia compared to the European countries, and 3 species (Artemisia rubripes, A. selengensis, Potentilla tergemina) were found also in the adjacent area - in the Ukraine. A majority of them was found near railway stations and along railway tracks, but their findings are rare. Among accidentals, several species showed transit distribution through the European Russia territory father to the west. For example, Artemisia umbrosa (Leonova 1994) is so-called "railway" plant; in the European Russia’s territory, it was recorded mainly along railway beds and slopes where sometimes it forms dense thickets. Railways are known to be preferential migration corridors for some invasive plants and to promote the rapid spread of non-native plant species (Nazarov 1927, Mack 2003). Despite the low density of railway tracks $\left(0.51 \mathrm{~km}\right.$ per $\left.100 \mathrm{~km}^{2}\right)$, Russia is the second in the world by the length of the railway network, which is about $87,000 \mathrm{~km}$. Information about the importation of plants on the transport routes are known from the very beginning of the operation of railways in Russia (in the second half of $19^{\text {th }}$ century). The substantial increase of the flow of alien plants by railways was noted at the beginning of the $20^{\text {th }}$ century in connection with the movement of troops during the World War I and the Civil war (Nazarov 1927). However, this fact was known mainly for transportation of plants on the territory of European Russia, and an information about the far drift (for example, from the Far East) at this time is absent. Nevertheless, the findings of some species during recent 40 years solely on the railway suggest that this pathway is a just species dispersal mechanism (Fig. 4). The first findings of Artemisia umbrosa made in 1970-1980s (Gusev 1980, Maiorov et al. 1993); now the species distribution extended over 18 regions. The railway, connecting the Russian Far East and European Russia, passes through the native area of this species that occupies southern areas of Eastern Siberia and Far East, but direct vector transfer of plant propagules is unknown (it may be ballast, train, people or cargo). Initial contact in the area of influence of the railway may be associated with the ballast for the construction of railway tracks and with humans. As well, railway habitats represented a suitable environment for species with different ecological requirements (Hansen \& Clevenger 2005). In European Russia Artemisia umbrosa usually was occurred locally and did not occupy the whole territory of any of the regions, but was naturalized in eight regions. Besides European Russia Artemisia umbrosa was mentioned in Lithuania (Gudžinskas 1997), Belarus (Identification guide 1999) and in the Ukraine (Mosyakin 1990, Mosyakin \& Yavorska 2002, Greuter \& Raab-Straube 2005). In 2009, this species was collected in the northeastern Romania (Sírbu \& Oprea 2011) where it was accidental, through the rail transport from the east. Another species Artemisia argyi had a similar history and was reported from six European Russia's regions (material of database), from the Ukraine (Mosyakin 1990) and recently was found in Romania in close proximity to railway (Sírbu \& Oprea 2011).

For European Russia, East Asian species are an example of long-distance drift of species, predominance of escapes among them confirms the importance of deliberate intro- duction mode in process of plant invasion. With regard to accidental species, European Russia may be considered as one of the corridor for introducing alien species of Asian as well as of East Asian origin father to Europe.

\section{ACKNOW LEDGEMENTS}

Thanks are due Dr. Yurii E. Alexeev (Moscow University, Moscow) for providing data on life forms of alien species, Dr. M.E. Fleis and M.M. Borisov (Institute of Geography RAS, Moscow) for the background of maps. Dr. R.N. Mack and anonymous reviewer are acknowledged for their comments on the manuscript. This study was supported by Russian Foundation for Basic Research (grants 12-0400467, 12-04-10051-k, 13-04-10085-k).

\section{LITERATURE CITED}

Cherepanov, S.K. 1995. Vascular plants of Russia and adjacent countries. World and Family-95 Ltd, Saint Petersburg, 992 p. (in Russian). [Черепанов С.К. 1995. Сосудистые растения России и сопредельных государств. Санкт-Петербург: Мир и семья-95. 992 с.]

Dickoré, W. \& G. Kasparek 2010. Species of Cotoneaster Rosaceae, Maloideae) indigenous to, naturalising or commonly cultivated in Central Europe. Willdenowia 40: 13-45.

Fridley, J.D. 2008. Of Asian Forests and European Fields: Eastern U.S. Plant Invasions in a Global Floristic Context. PLoS ONE 3(11): e3630. doi:10.1371/journal.pone.0003630

Greuter, W. \& E. von Raab-Straube (eds.). 2005. Euro+Med Notulae, 1. Willdenowia 35:223-239.

Grigorievskava, A.Ya., E.A. Starodubtseva, N.Yu. Khlyzova \& V.A Agafonov 2004. Adventive flora of the Voronezh Region: historical, biogeographical, ecological aspects. Voronezh University Press, Voronezh. 320 p. (in Russian). [Григорьевская А.Я., Стародуб̆цева Е.А., Хлызова Н.Ю., Агафонов В.А. 2004. ААвентивная флора Воронежской области: исторический, биогеографический, экомогический аспекты. Воронеж: ИзАательство Воронежского университета. 320 с.]

Grudzinskaya, I.A. 1977. The genus Ulmus L. - elm. In: Ranges of trees and shrubs of the USSR, vol. 1, pp. 126-132, Nauka, Leningrad (in Russian). [Грудзинская И.А. 1977. Род Ulmus L. - вяз, ильм, берест // Ареалы деревьев и кустарников СССР. Т. 1. А.: Наука. С. 126-132.]

Gudžinskas, Z. 1997. Conspectus of alien plant species of Lithuania. 4. Asteraceae. Botanica Lithuanica 3: 335-366.

Gusev, Yu.D. 1980. New information on adventive flora of various taiga zone's regions of European part of Russia. Botanicheskii Zhurnal 65(2): 249-255 (in Russian with English summary). Гусев Ю.А. 1980. Новые сведения об адвентивной флоре разных областей таежной зоны европейской части России // Ботанический журнац. Т. 65, № 2. С. 249-255.]

Hansen, M.J. \& A.P. Clevenger 2005. The influence of disturbance and habitat on the presence of non-native plant species along transport corridors. Biological Conservation 125: 249-259.

Hulme, P.E. 2009. Trade, transport and trouble: managing invasive species pathways in an era of globalization. Journal of Applied Ecology 46: 10-18.

Hulme, P.E., S. Bacher, M. Kenis, S. Klotz, I. Kühn, D. Minchin, W. Nentwig et al. 2008. Grasping at the routes of biological invasions: A framework for integrating pathways into policy. Journal of Applied Ecology 45: 403-414.

Jiang, H., Q. Fan, J.-T. Li, Shi S., S.-P. Li, W.-B. Liao \& W.-S. Shu 2011. Naturalization of alien plants in China. Biodiversity and Conservation 20: 1545-1556.

Ignatov, M.S., V.V. Makarov \& A.V. Chichev 1990. Conspectus of adventive flora of the Moscow Region. In: Investigations of the flora of the Moscow Region (A.K. Skvortzov, ed.), pp. 5-105, Nauka, Moscow (in Russian with English summary). [Игнатов M.С., Макаров В.В., Чичев А.В. 1990. Конспект флоры аАвентивных растений Московской области // ФАорис- 
тические исследования в Московской области / Отв. реА. А.К. Скворцов. Москва: Наука. С. 5-105.]

Křivánek, M., P. Pyšek \& V. Jarošík 2005. Planting History and Propagule Pressure as Predictors of Invasion by Woody Species in a Temperate Region. Conservation Biology 20(5): 1487-1498.

Laiviņš, M., M. Bice, I. Krampis, Dz. Knape, D. Šmite \& V. Šulcs 2009. Latvijas kokangu atlants. Latvijas Universitātes Biologiijas institūts, Apgāds Mantojums [online] http://www.kurtuesi.lv/ flora

Lambdon, P.W., P. Pyšek, C. Basnou, M. Hejda, M. Arianoutsou, F. Essl, V. Jarošík et al. 2008. Alien flora of Europe: species diversity, temporal trends, geographical patterns and research needs. Preslia 80: 101-149.

Leonova, T.G. 1994. Wormwood - Atremisia L. In: Flora of the European Part of the USSR, vol. VII (N.N. Tzvelev, ed.), pp. 150-174, Nauka, Leningrad (in Russian). [Аеонова Т.Г. 1994. Полынь - Artemisia L. // ФАора европейской части СССР. T. VII Под реА. Н.Н. Цвелева. АенинграА: Наука. С. 150-174.]

Liatukas, Ž. \& V. Stukonis 2009. Zizania latifolia - a new alien plant in Lithuania. Botanica Lithuanica 15(1): 17-24.

Lonsdale, W.M. 1999. Global patterns of plant invasions and the concept of invasibility. Ecology 80: 1522-1536.

Mack, R.N. 2003. Global plant dispersal, naturalization and invasion: pathways, modes and circumstances. In: Invasive Species. Vectors and Management Strategies (G. Ruiz \& J. Carlton, eds.), pp. 3-30, Island Press.

Mack, R.N., D. Simberloff, W.M. Lonsdale, H. Evans, M. Clout \& F.A. Bazzaz 2000. Biotic invasions: causes, epidemiology, global consequences, and control. Ecological Applications 10(3): 689-710.

Maevsky, P.F. 2006. Flora of the middle part of European Russia. $10^{\text {th }}$ edition. KMK Scientific Press, Moscow. 600 p. (in Russian). [Maевский П.Ф. 2006. ФАора средней полосы европейской части России. 10-е издание. Москва: Товарищество научных изАаний КМК. 600 с.]

Maiorov, S.R., L.F. Volosnova \& E.A. Daragan 1993. New floristic records in the Kaluga Region. Bulletin of Moscow Natural Society, biology department 98(6): 118-121 (in Russian with English summary). [Майоров С.Р., Волоснова А.Ф., Аараган E.А. 1993. Новые флористические находки в Калужской области. Бюлметень МОИП, отА. биолог. Т. 88, вып. 6. С. 118-121.]

Mandák, B., P. Pyšek \& K. Bímová 2004. History of the invasion and distribution of Reynoutria taxa in the Czech Republic: a hybrid spreading faster than its parents. Preslia 76: 15-64.

Manual of the Alien Plants of Belgium. Last modified 18 February 2013 [online] http://alienplantsbelgium.be/

Morozova, O.V. 2002. Database on adventive plant species (Alien plant Species). In: Proceeding of the Conference on Environmental Safety. IUCN, Moscow. P. 83-94 (in Russian). [Морозова O.B. 2002. База данных по аАвентивным видам растений (Alien plant Species) // Материалы совещания по экологической безопасности России. М.: IUCN. C. 83-94.]

Morozova, O.V. \& M.M. Borisov 2010. Web-Oriented Geoinformation System on Alien Plant Species of European Russia. Russian Journal of Biological Invasions 2: 47-55.

Morozova, O.V., E.A. Starodubtzeva \& N.G. Tzarevskaya 2008. Adventive flora of European Russia: inventory results. Proceedings of the Russian Academy of Sciences, series Geography 5: 85-94 (in Russian with English summary). [Морозова O.B., Стародубцева Е.А., Царевская Н.Г. 2008. ААвентивная флора Европейской России: итоги инвентаризации // Известия РАН, серия географическая. № 5. С. 85-94.]

Mosyakin, S.L. 1990. New and noteworthy alien species of Artemisia L. (Asteraceae) in the Ukrainian SSR. Ukrainskii Botanichnii Zhurnal 47(4): 10-13. [Mosyakin, S.L. 1990. New and noteworthy alien species of Artemisia L. (Asteraceae) in the Ukrainian SSR // Український ботанічний журнац. Т. 47, № 4, С. 10-13.]

Mosyakin, S.L. \& O.G. Yavorska 2002. The Nonnative Flora of the Kiev (Kyiv) Urban Area, Ukraine: A Checklist and Brief Analysis. Urban habitats 1(1): 45-65.

Nazarov, M.I. 1927. Adventive flora of the Central and Northern parts of the RSFSR during a time of war and revolution. Proceedings of the Main Botanical garden 26(3): 223-234 (in Russian). [Назаров М.И. 1927. ААвентивная флора средней и северной части РСФСР за время войны и революции / / Известия ГАавного ботанического саАа. Т. 26, вып. 3. С. 223-234.]

NOBANIS - North European and Baltic Network on Invasive Alien Species [online] http://www.nobanis.org

Notov, A.A. 2009. Adventive component of the Tver Region's flora: dynamics of composition and structure. Tver State University, Tver. $473 \mathrm{p}$. (in Russian). [Нотов А.А. 2009. ААвентивный компонент флоры Тверской области: Аинамика состава и структуры. Тверь: Тверской государственный университет. 473 с.]

Olden, J.D. \& N.L. Poff 2003. Toward a mechanistic understanding and prediction of biotic homogenization. American Naturalist 162(4): 442-460.

Ööpik, M., T. Kukk, K. Kull \& T. Kull 2008. The importance of human mediation in species establishment: analysis of the alien flora of Estonia. Boreal Environment Research 13: 53-67.

Parfyonov, V.I. (ed.). Identification guide of vascular plants of Belarus. 1999. Design PRO, Minsk, 472 p. (in Russian). [Опрелелитель высших растений Беларуси / Под реА. В.И. Парфенова. 1999. Минск: Аизайн ПРО. 472 с.]

Phillips, M.L., B.R. Murray, P. Pyšek, J. Pergl, V. Jarošík, M. Chytrý \& I. Kühn 2010. Plant species of the Central European flora as aliens in Australia. Preslia 82: 465-482.

Prinzing, A., W. Durka, S. Klotz \& R. Brandl 2002. Which species become aliens? Evolutionary Ecology Research 4: 385-405.

Pyšek, P. 1998. Is there a taxonomic pattern to plant invasions? Oikos 82: 282-294.

Pyšek, P., J. Danihelka, J. Sádlo, J.Jr. Chrtek, M. Chytrý, V. Jarošík, Z. Kaplan et al. 2012. Catalogue of alien plants of the Czech Republic (2nd edition): checklist update, taxonomic diversity and invasion patterns. Preslia 84: 155-255.

Pyšek, P. \& D.M. Richardson 2006. The biogeography of naturalization in alien plants. Journal of Biogeography 33: 2040-2050.

Pyšek, P. \& D.M. Richardson 2007. Traits Associated with Invasiveness in Alien Plants: Where Do we Stand? In: Biological Invasions. Ecological Studies, vol. 193 (W. Nentwig, ed.), pp. 97-125, Springer-Verlag, Berlin, Heidelberg.

Richardson, D.M. \& P. Pyšek 2006. Plant invasions: merging the concepts of species invasiveness and community invisibility. Progress in Physical Geography 30(3): 409-431.

Richardson, D.M., P. Pyšek, M. Rejmánek, M.G. Barbour, F.D. Panetta \& C.J. West 2000. Naturalization and invasion of alien plants: concepts and definitions. Diversity and Distributions 6: 93-107.

Qian, H. 2002. A comparison of the taxonomic richness of temperate plants in East Asia and North America. American Journal of Botany 89: 1818-1825.

Qian, H. \& R.E. Ricklefs 2000. Large-scale processes and the Asian bias in species diversity of temperate plants. Nature 407: 180-182.

Qian, H. \& R.E. Ricklefs 2006. The role of exotic species in homogenizing the North American flora. Ecology Letters 9: 12931298

Simberloff, D. 1997. Nonindigenous species - a global threat to biodiversity and stability. In: Nature and human society: the quest for a sustainable world. Proceedings of the 1997 Forum on Biodiversity (P.H. Raven, ed.), pp. 325-334, Academy Press, Washington.

Sírbu, C. \& A. Oprea 2011. New records in the alien flora of Romania (Artemisia argyi, A. lavandulaefolia) and Europe (A. lancea). Turkish Journal of Botany 35: 717-728.

Skvortsov, A.K. 1999. Willows of Russia and Adjacent Countries. Taxonomical and Geographical Revision. University of Joensuu, Joensuu. $307 \mathrm{p}$.

Stohlgren, T.J., P. Pyšek, J. Kartesz, M. Nishino, A. Pauchard, M. Winter, J. Pino et al. 2011. Widespread plant species: natives versus aliens in our changing world. Biological Invasions 13(9): 1931-1944.

Takhtajan, A.L. 1978. The floristic regions of the world. Nauka, Leningrad. 248 p. (in Russian). [Тахтаджян А.А. 1978. ФАористические области Земли. АенинграА: Наука. 248 с.] 
Thuiller, W., D.M. Richardson, M. Rouget, S. Proches \& J.R.U. Wilson 2006. Interactions between environment, species traits and human uses describe patterns of plant invasion. Ecology 87(7): 1755-1769.

Tuganaev, V.V. \& A.N. Puzyrev 1988. Hemerophytes of the VolgaKama interfluve. Press of Ural University, Sverdlovsk. 128 p. (in Russian). [Туганаев B.В., Пузырев А.Н. 1988. Гемерофиты Волжско-Камского межАуречья. СверАловск: Издательство Уральского университета. 128 с.]

Vinogradova, J.K., S.R. Maiorov \& L.V. Khorun 2009. Black book of the Central Russia: alien plant species in ecosystems of the Central Russia. GEOS, Moscow, 512 p. (in Russian). [Виноградова Ю.К., Майоров С.Р., Хорун А.В. 2009. Черная книга Средней России: чужеродные виды растений в экосистемах Средней России. Москва: ГЕОС. 512 с.]

Vinogradova, J.K., S.R. Maiorov \& A.A. Notov 2011. Black book of the Tver Area's flora: alien plant species in ecosystems of the Tver Region. KMK Scientific Press, Moscow, 292 p. (in Russian). [Виноградова Ю.К., Майоров С.Р., Нотов А.А. 2011. Черная книга Тверской области: чужеродные виды растений в экосистемах Тверского региона. Москва: Товарищество научных изданий КМК. 292 с.]

Vitousek, P.M., C.M. D’Antonio, L.L. Loope, M. Rejmánek \& R. Westbrooks 1997. Introduced species: a significant component of human-caused global change. New Zealand Journal of Ecology 21(1): 1-16.

Weber, E., S-G. Sun \& B. Li 2008. Invasive alien plants in China: diversity and ecological insights. Biological Invasions 10: $1411-$ 1429.

Zelenskaya, O.V. 2011. Weeds of the Kuban rice fields. In: Weedy plants in the changing world: topical issues in studying their diversity, origin and evolution. Proceedings of the I International Scientific Conference, pp. 93-99, VIR, Saint Petersburg (in Russian with English summary). [Зеленская О.В. 2011. Сорные растения рисовых полей Кубани // Сорные растения в изменяющемся мире: актуальные вопросы изучения разнообразия, происхожАения, эволюции. Материалы I межАународной научной конференции. Санкт-Петербург: ВИР. С. 93-99.]

\section{Appendix 1. East Asian species recorded in European Russia}

Species are arranged alphabetically. LH - life history: $\mathrm{tr}$ - tree, shrub, pr - herbaceous perennial, bn - biennial, an - annual. Path - pathway of introduction into European Russia: D - deliberate planting involved; A - accidental (unintentional) pathway only. Regions: all - number of all regions where species was occurred, nat - number of regions where species was naturalized (not including regions where species was invasive)

\begin{tabular}{|c|c|c|c|c|c|c|}
\hline \multirow[t]{2}{*}{ Species } & \multirow[t]{2}{*}{ Family } & \multicolumn{2}{|c|}{ Life form } & \multirow[t]{2}{*}{ Path } & \multicolumn{2}{|c|}{ Regions } \\
\hline & & Raunkier & LH & & all & nat \\
\hline Acer ginnala & Aceraceae & phanerophyte & sh & $\mathrm{D}$ & 21 & 10 \\
\hline Acer tegmentosum & Aceraceae & phanerophyte & $\operatorname{tr}$ & $\mathrm{D}$ & 1 & 1 \\
\hline Aconogonon divaricatum & Polygonaceae & hemicryptophyte & $\mathrm{pr}$ & $\mathrm{A}$ & 8 & 5 \\
\hline Aconogonon savatieri & Polygonaceae & hemicryptophyte & $\mathrm{pr}$ & $\mathrm{D}$ & 3 & 0 \\
\hline Aconogonon weyrichii & Polygonaceae & hemicryptophyte & $\mathrm{pr}$ & $\mathrm{D}$ & 14 & 4 \\
\hline Actinidia chinensis & Actinidiaceae & phanerophyte & $\mathrm{sh}$ & $\mathrm{D}$ & 1 & 0 \\
\hline Adenocaulon adhaerescens & Asteraceae & hemicryptophyte & $\mathrm{pr}$ & $\mathrm{D}$ & 1 & 0 \\
\hline Agastache rugosa & Lamiaceae & hemicryptophyte & $\mathrm{pr}$ & $\mathrm{D}$ & 2 & 0 \\
\hline Ailanthus altissima & Simaroubaceae & phanerophyte & $\operatorname{tr}$ & $\mathrm{D}$ & 4 & 3 \\
\hline Allium tuberosum & Alliaceae & geophyte & $\mathrm{pr}$ & $\mathrm{D}$ & 1 & 0 \\
\hline Arisaema amurense & Araceae & geophyte & $\mathrm{pr}$ & $\mathrm{D}$ & 1 & 0 \\
\hline Artemisia argyi & Asteraceae & hemicryptophyte & $\mathrm{pr}$ & $\mathrm{A}$ & 6 & 1 \\
\hline Artemisia desertorum & Asteraceae & hemicryptophyte & $\mathrm{pr}$ & $\mathrm{A}$ & 1 & 0 \\
\hline Artemisia feddei & Asteraceae & hemicryptophyte & $\mathrm{pr}$ & $\mathrm{A}$ & 1 & 0 \\
\hline Artemisia opulenta & Asteraceae & hemicryptophyte & $\mathrm{pr}$ & $\mathrm{A}$ & 1 & 0 \\
\hline Artemisia rubripes & Asteraceae & hemicryptophyte & $\mathrm{pr}$ & $\mathrm{A}$ & 2 & 0 \\
\hline Artemisia selengensis & Asteraceae & hemicryptophyte & $\mathrm{pr}$ & $\mathrm{A}$ & 5 & 0 \\
\hline Artemisia umbrosa & Asteraceae & hemicryptophyte & $\mathrm{pr}$ & $\mathrm{A}$ & 19 & 8 \\
\hline Astilbe chinensis & \begin{tabular}{|l} 
Saxifragaceae \\
\end{tabular} & hemicryptophyte & $\mathrm{pr}$ & $\mathrm{D}$ & 2 & 0 \\
\hline Berberis thunbergii & Berberidaceae & phanerophyte & $\mathrm{sh}$ & $\mathrm{D}$ & 3 & 2 \\
\hline Callistephus chinensis & Asteraceae & \begin{tabular}{|l|} 
therophyte \\
\end{tabular} & an & $\mathrm{D}$ & 14 & 0 \\
\hline Celastrus orbiculata & Celastraceae & phanerophyte & $\mathrm{sh}$ & $\mathrm{D}$ & 1 & 0 \\
\hline Cerasus tomentosa & Rosaceae & phanerophyte & sh & $\mathrm{D}$ & 17 & 9 \\
\hline Chaenomeles japonica & Rosaceae & phanerophyte & $\mathrm{sh}$ & $\mathrm{D}$ & 6 & 0 \\
\hline Citrus unshiu & Rutaceae & phanerophyte & $\operatorname{tr}$ & $\mathrm{D}$ & 1 & 0 \\
\hline Claytonia sibirica & Portulacaceae & therophyte & an & $\mathrm{D}$ & 1 & 0 \\
\hline Clematis serratifolia & Ranunculaceae & hemicryptophyte & $\mathrm{pr}$ & $\mathrm{D}$ & 2 & 1 \\
\hline Commelina communis & Commelinaceae & therophyte & an & $\mathrm{A}$ & 17 & 0 \\
\hline Corispermum elongatum & Chenopodiaceae & therophyte & an & $\mathrm{A}$ & 2 & 0 \\
\hline Corydalis ochotensis & Fumariaceae & $\begin{array}{l}\text { hemicryptophyte, } \\
\text { therophyte }\end{array}$ & an, bn & $\mathrm{D}$ & 2 & 0 \\
\hline
\end{tabular}




\begin{tabular}{|c|c|c|c|c|c|c|}
\hline Appendix 1. Continued & & & & & & \\
\hline Cotoneaster lucidus & Rosaceae & phanerophyte & sh & $\mathrm{D}$ & 14 & 7 \\
\hline Crataegus chlorosarca & Rosaceae & phanerophyte & $\operatorname{tr}$ & $\mathrm{D}$ & 1 & 0 \\
\hline Crataegus dahurica & Rosaceae & phanerophyte & $\mathrm{sh}$ & $\mathrm{D}$ & 2 & 2 \\
\hline Crataegus maximowiczii & Rosaceae & phanerophyte & $\operatorname{tr}$ & $\mathrm{D}$ & 4 & 0 \\
\hline Crataegus pinnatifida & Rosaceae & phanerophyte & sh & $\mathrm{D}$ & 3 & 1 \\
\hline Descurainia sophioides & Brassicaceae & therophyte & an & $\mathrm{A}$ & 1 & 0 \\
\hline Dianthus chinensis & Caryophyllaceae & hemicryptophyte & $\mathrm{pr}$ & $\mathrm{D}$ & 1 & 0 \\
\hline Diospyros kaki & Ebenaceae & phanerophyte & $\operatorname{tr}$ & $\mathrm{D}$ & 1 & 0 \\
\hline Echinochloa caudata & Poaceae & therophyte & an & $\mathrm{A}$ & 5 & 1 \\
\hline Echinochloa utilis & Poaceae & therophyte & an & $\mathrm{D}$ & 1 & 0 \\
\hline Eragrostis multicaulis & Poaceae & therophyte & an & $\mathrm{A}$ & 4 & 0 \\
\hline Eriochloa villosa & Poaceae & therophyte & an & A & 3 & 0 \\
\hline Fagopyrum tataricum & Polygonaceae & therophyte & an & $\mathrm{A}$ & 26 & $2 ?$ \\
\hline Fraxinus mandshurica & Oleaceae & phanerophyte & $\operatorname{tr}$ & $\mathrm{D}$ & 1 & 1 \\
\hline Fraxinus rhynchophylla & Oleaceae & phanerophyte & $\operatorname{tr}$ & $\mathrm{D}$ & 1 & 1 \\
\hline Glycine max & Fabaceae & therophyte & an & $\mathrm{D}, \mathrm{A}$ & 11 & 0 \\
\hline Hemerocallis fulva & Hemerocallidaceae & geophyte & $\mathrm{pr}$ & $\mathrm{D}$ & 12 & 6 \\
\hline Heteropappus biennis & Astaraceae & hemicryptophyte & pr & $\mathrm{D}$ & 2 & 0 \\
\hline Hordeum jubatum & Poaceae & hemicryptophyte & $\mathrm{pr}$ & $\mathrm{D}, \mathrm{A}$ & 32 & 9 \\
\hline Hylomecon vernalis & Papaveraceae & hemicryptophyte & $\mathrm{pr}$ & $\mathrm{D}$ & 1 & 0 \\
\hline Juglans mandshurica & Juglandaceae & phanerophyte & $\operatorname{tr}$ & $\mathrm{D}$ & 14 & 7 \\
\hline Lespedeza bicolor & Fabaceae & phanerophyte & $\mathrm{sh}$ & $\mathrm{D}$ & 1 & 1 \\
\hline Ligularia przewalskii & Asteraceae & hemicryptophyte & $\mathrm{pr}$ & $\mathrm{D}$ & 2 & 0 \\
\hline Ligustrina amurensis & Oleaceae & phanerophyte & $\mathrm{sh}$ & $\mathrm{D}$ & 1 & 1 \\
\hline Lilium lancifolium & Liliaceae & geophyte & $\mathrm{pr}$ & $\mathrm{D}$ & 2 & 0 \\
\hline Lilium maculatum & Liliaceae & geophyte & $\mathrm{pr}$ & $\mathrm{D}$ & 2 & 0 \\
\hline Lonicera ruprechtiana & Caprifoliaceae & phanerophyte & $\mathrm{sh}$ & $\mathrm{D}$ & 1 & 0 \\
\hline Lycium barbarum & Solanaceae & phanerophyte & sh & $\mathrm{D}$ & 7 & 4 \\
\hline Lycium chinense & Solanaceae & phanerophyte & sh & $\mathrm{D}$ & 1 & 0 \\
\hline Malus baccata & Rosaceae & phanerophyte & $\operatorname{tr}$ & $\mathrm{D}$ & 20 & 10 \\
\hline Malus mandshurica & Rosaceae & phanerophyte & $\operatorname{tr}$ & $\mathrm{D}$ & 1 & 0 \\
\hline Malus prunifolia & Rosaceae & phanerophyte & $\operatorname{tr}$ & $\mathrm{D}$ & 17 & 2 \\
\hline Malva verticillata & Malvaceae & therophyte & an & $\mathrm{D}, \mathrm{A}$ & 18 & 0 \\
\hline Meehania urticifolia & Lamiaceae & hemicryptophyte & $\mathrm{pr}$ & $\mathrm{D}$ & 1 & 0 \\
\hline Menispermum dauricum & Menispermaceae & chamaephyte & $\mathrm{ch}$ & $\mathrm{D}$ & 2 & 2 \\
\hline Monochoria korsakowii & Pontederiaceae & therophyte & an & A & 2 & 0 \\
\hline Morus alba & Moraceae & phanerophyte & $\operatorname{tr}$ & $\mathrm{D}$ & 9 & 3 \\
\hline Padus maackii & Rosaceae & phanerophyte & $\operatorname{tr}$ & $\mathrm{D}$ & 8 & 3 \\
\hline Panicum milliaceum & Poaceae & therophyte & an & $\mathrm{D}, \mathrm{A}$ & 25 & 1 \\
\hline Perilla frutescens & Lamiaceae & therophyte & an & $\mathrm{D}$ & 3 & 0 \\
\hline Persica vulgaris & Rosaceae & phanerophyte & $\operatorname{tr}$ & $\mathrm{D}$ & 4 & 0 \\
\hline Phellodendron amurense & Rutaceae & phanerophyte & $\operatorname{tr}$ & $\mathrm{D}$ & 4 & 1 \\
\hline Pinus koraiensis & Pinaceae & phanerophyte & $\operatorname{tr}$ & $\mathrm{D}$ & 2 & 0 \\
\hline Polygonum sabulosum & Polygonaceae & therophyte & an & A & 4 & 0 \\
\hline Populus simonii & Salicaceae & phanerophyte & $\operatorname{tr}$ & $\mathrm{D}$ & 3 & 2 \\
\hline Populus suaveolens & Salicaceae & phanerophyte & $\operatorname{tr}$ & $\mathrm{D}$ & 11 & 5 \\
\hline Potentilla tergemina & Rosaceae & hemicryptophyte & pr & A & 3 & 1 \\
\hline Pyrus ussuriensis & Rosaceae & phanerophyte & $\operatorname{tr}$ & $\mathrm{D}$ & 6 & 3 \\
\hline Reynoutria japonica & Polygonaceae & hemicryptophyte & $\mathrm{pr}$ & $\mathrm{D}$ & 24 & 12 \\
\hline Reynoutria sachalinensis & Polygonaceae & hemicryptophyte & $\mathrm{pr}$ & $\mathrm{D}$ & 19 & 13 \\
\hline Rheum compactum & Polygonaceae & hemicryptophyte & $\mathrm{pr}$ & $\mathrm{D}$ & 1 & 0 \\
\hline Rodgersia podophylla & Saxifragaceae & hemicryptophyte & $\mathrm{pr}$ & $\mathrm{D}$ & 1 & 0 \\
\hline Rosa rugosa & Rosaceae & phanerophyte & $\mathrm{sh}$ & $\mathrm{D}$ & 28 & 11 \\
\hline Rosa $\times$ kamtschatica & Rosaceae & phanerophyte & $\mathrm{sh}$ & $\mathrm{D}$ & 1 & 0 \\
\hline
\end{tabular}




\begin{tabular}{|l|l|l|c|c|c|c|}
\hline Appendix 1. Continued & & & & \\
\hline Salix babylonica & Salicaceae & phanerophyte & tr & $\mathrm{D}$ & 2 & 1 \\
\hline Schisandra chinensis & Schisandraceae & phanerophyte & sh & $\mathrm{D}$ & 6 & 1 \\
\hline Securinega suffruticosa & Euphorbiaceae & phanerophyte & sh & $\mathrm{A}$ & 1 & 0 \\
\hline Senecio argunensis & Asteraceae & hemicryptophyte & $\mathrm{pr}$ & $\mathrm{D}$ & 1 & 0 \\
\hline Setaria faberi & Poaceae & therophyte & an & $\mathrm{A}$ & 7 & 0 \\
\hline Sorbaria sorbifolia & Rosaceae & phanerophyte & sh & $\mathrm{D}$ & 25 & 16 \\
\hline Sorbus sambucifolia & Rosaceae & phanerophyte & $\mathrm{D}$ & 1 & 0 \\
\hline Sphallerocarpus gracilis & Apiaceae & hemicryptophyte & bn & $\mathrm{A}$ & 2 & 0 \\
\hline Spiraea japonica & phanerophyte & sh & $\mathrm{D}$ & 7 & 4 \\
\hline Spiraea media & Rosaceae & phanerophyte & sh & $\mathrm{D}$ & 15 & 12 \\
\hline Spiraea nipponica & Rosaceae & phanerophyte & sh & $\mathrm{D}$ & 2 & 1 \\
\hline Spiraea salicifolia & Rosaceae & sh & $\mathrm{D}$ & 17 & 14 \\
\hline Swida brachypoda & Rosaceae & phanerophyte & $\mathrm{D}$ & 1 & 0 \\
\hline Syringa villosa & Cornaceae & phanerophyte & sh & $\mathrm{D}$ & 2 & 0 \\
\hline Taraxacum sinicum & Oleaceae & hemicryptophyte & $\mathrm{pr}$ & $\mathrm{A}$ & 2 & 0 \\
\hline Thladiantha dubia & Astaraceae & geophyte & $\mathrm{pr}$ & $\mathrm{D}$ & 20 & 8 \\
\hline Ulmus pumila & Cucurbitaceae & phanerophyte & tr & $\mathrm{D}$ & 27 & 13 \\
\hline Vitis amurensis & Ulmaceae & phanerophyte & sh & $\mathrm{D}$ & 2 & 1 \\
\hline Waldsteinia ternata & Vitaceae & hemicryptophyte & pr & $\mathrm{D}$ & 1 & 0 \\
\hline Weigela praecox & Rosaceae & phanerophyte & sh & $\mathrm{D}$ & 1 & 0 \\
\hline Zizania latifolia & Caprifoliaceae & helophyte & $\mathrm{D}$ & 16 & 9 \\
\hline
\end{tabular}

